Mitchell, P. \& MoyLe, J. (1951). J. gen. Microbiol. 5, 981-992.

\title{
The Glycerophospho-protein Complex Envelope of Micrococcus pyogenes
}

\author{
By P. MITCHELL AND JENNIFER MOYLE \\ Department of Biochemistry, University of Cambridge
}

SUMMARY: The glycerophospho-compound which has been shown to account for more than one-quarter of the total organic phosphate of Micrococcus pyogenes is present almost exclusively in the particulate fractions of mechanically disintegrated cell suspensions.

The main particulate fraction corresponds to the cell envelope material of Dawson (1949). Three-quarters of the weight of this material is made up of a glycerophosphoprotein complex of which the protein moiety resembles silk fibroin in amino-acid composition and in its general properties. The amount of hydroxylamino-acid in the protein of the envelope would be sufficient to bind the polyolphosphoric acids covalently, but the possibility that the polyolphosphoric acids form a polymer which is adsorbed on to a protein matrix is not excluded.

A subsidiary particulate fraction, made up of very small particles containing a high proportion of phospholipid, was found to be otherwise similar in composition to the envelope fraction. It is suggested that in the intact cell, the material of the small particle fraction may form a continuous layer (lipid membrane?) lying beneath the glycerophospho-protein complex envelope (cell wall?).

It has been inferred from observations on the release of glycerophosphate from $\boldsymbol{M}$. pyogenes by hydrolysis in dilute acid or alkali, that a large amount of a readily hydrolysed glycerophospho-compound is present (Mitchell \& Moyle, $1951 b$ ). It was desirable to determine the nature of the complex in which the glycerophosphate is bound, and hence to isolate the intact glycerophosphocompound. The present paper describes the isolation and partial characterization of two particulate fractions of $M$. pyogenes var. aureus (strain Duncan) which contain the major part of the glycerophosphate. Some implications of this work have been published (Mitchell \& Moyle, 1950).

\section{EXPERIMENTAL}

In the course of preparing the ribonucleoprotein of Micrococcus pyogenes by disintegrating a cell suspension in distilled water and precipitating the nucleoprotein according to the method of Sevag \& Smolens (1941) with 60-66\% saturated ammonium sulphate, it was noted that most of the phosphate in excess of that which could be accounted for as nucleotide units of ribonucleic acid (RNA) (XSP = total organic P-RNA, expressed in $\mu \mathrm{mol} / \mathrm{g}$. cell dry weight) was contained in the water-insoluble debris centrifuged down in $1 \mathrm{hr}$. at $3000 \mathrm{~g}$, while a smaller portion appeared in the centrifugate fraction precipitated by $60 \%$ saturated ammonium sulphate. Table 1 shows the relevant data and the methods of estimation, the meaning of the symbols being as previously described (Mitchell \& Moyle, 1951 b). It thus appeared likely that 
the glycerophospho-compound of $M$. pyogenes would be found in the particulate fractions of mechanically disintegrated cell suspensions. Accordingly, we proceeded to prepare and examine the appropriate fractions of $M$. pyogenes grown under the same conditions as before.

Table 1. The 'excess phosphate' (XSP) content of water insoluble and ammonium sulphate precipitable fractions of mechanically disintegrated Micrococcus pyogenes

$\begin{array}{cccc} & \text { Total } & & \\ \text { Fraction } & \text { organic P } & \text { RNA } & \text { XSP } \\ \text { Insoluble } & 230 & - & 230 \\ 0-60 \% * & 61.5 & 46 & 15.5 \\ 60-66 \% & 62.5 & 62.5 & 0 \\ 66-80 \% & \mathbf{7 2 . 0} & \mathbf{7 0 . 5} & \mathbf{1 . 5}\end{array}$

* Figures show percentage saturation with ammonium sulphate required to precipitate the fraction.

\section{Preparation of fractions}

Disintegration of cells. The cells were disintegrated by the method of Mickle (1948). The two cylindrical containers $(22 \mathrm{~mm}$. internal diameter, $50 \mathrm{~mm}$. internal height, mounted vertically) were each filled with $4 \mathrm{~g}$. of Ballotini glass-balls no. 12, (Chance Bros. Ltd., Birmingham), $10 \mathrm{ml}$. of distilled water and $250 \mathrm{mg}$. of freeze-dried organism and vibrated at $50 \mathrm{cyc}$. $/ \mathrm{sec}$. for $1 \mathrm{hr}$. at room temperature. After this treatment, stained smears (Gram) showed less than $1 \%$ intact cells. The froth and underlying opalescent suspension were transferred quantitatively from the containers to a centrifuge tube, together with ten washings of the Ballotini balls with $1 \mathrm{ml}$. sample of distilled water.

Separation of fractions. The froth was broken by centrifuging for $5 \mathrm{~min}$. at $1000 \mathrm{~g}$ and the Ballotini held by the froth were released. The centrifugate was transferred quantitatively to a celluloid centrifuge tube, leaving a small pad of partially disintegrated cells with the Ballotini. The suspension was now centrifuged at $3000 \mathrm{~g}$ for $\mathbf{1 ~ h r}$., and material was deposited in two distinct layers, the lower layer being white and opaque and the upper one yellow and transparent. After decanting most of the opalescent centrifugate, it was possible by gently agitating the tube to redisperse the yellow material in the remaining supernatant liquid without disturbing the underlying layer. The supernatant was removed with a bulb pipette and the surface of the underlying layer was washed with a little distilled water, the latter being added to the residue of partially disintegrated cells. The supernatant and original centrifugate were combined and centrifuged at 15,000 $\mathrm{g}$ for $1 \mathrm{hr}$. to deposit the yellow material from which an almost clear centrifugate could be decanted. Both the white and yellow deposits were submitted to a further similar differential centrifugation after redispersing in small volumes of distilled water. The appropriate parts were combined to give four fractions:

(i) Envelope fraction (see below), corresponding to the opaque white material centrifuging down rapidly at $3000 \mathrm{~g}$. 
(ii) Small particle fraction, corresponding to the yellow material centrifuging down at $15,000 \mathrm{~g}$.

(iii) Soluble fraction, corresponding to the centrifugate separated from fraction (ii).

(iv) Residue fraction, consisting of partially broken cells, washings of the surface of the pad of fraction (i) and residues corresponding to fractions (ii) and (i) returned during the second differential centrifuging of fractions (i) and (ii) respectively.

The fractions were dried over $\mathrm{P}_{2} \mathrm{O}_{5}$ in vacuo at room temperature. The weights of the fractions obtained from $1 \mathrm{~g}$. of similarly dried $M$. pyogenes are shown in Table 2.

Table 2. The weights of the fractions of mechanically disintegrated Micrococcus pyogenes

$\begin{array}{ccc} & \text { Fraction } & \begin{array}{c}\text { Weight } \\ \text { (mg.) }\end{array} \\ \text { (i) } & \text { Envelope } & 166 \\ \text { (ii) Small particle } & 84 \\ \text { (iii) Soluble } & 626 \\ \text { (iv) Residue } & 102 \\ & \text { Total } & 978\end{array}$

The fractions were obtained from $1000 \mathrm{mg}$. of dried organism.

\section{Morphology of the fractions}

With the assistance of $\mathbf{M r}$ Horne of the Cavendish laboratory, the fractions were examined in the Siemens electron microscope after shadowcasting. with gold and palladium, and photographs were taken of representative specimens. Fraction (i) was found to consist of cell envelopes, closely resembling those first observed by Dawson (1949), practically uncontaminated by any other particulate material. Fraction (ii) showed mainly spherical particles 10-50 $\mathrm{m} \mu$. diameter. There was a relatively small proportion of flat fragments resembling parts of cell envelopes, but no intact cells or intact cell envelopes. Fraction (iv) contained mostly partially emptied cells, but also some of the material of fractions (i) and (ii).

On examining the fractions with the light microscope, it was found that the cell envelopes could be made visible by staining with amphipathic dyes such as Victoria blue, but that the material of the envelope fraction showed generally a very low affinity either for hydrophilic acidic and basic dyes or for the hydrophobic lipid-soluble ones. While the individual particles of the small particle fraction could not be discerned, the fixed material was found to stain intensely with lipid soluble dyes such as Sudan black.

Distribution of organic phosphate in whole cells and cell fractions

In the procedure adopted for determining the distribution of organic phosphate, most of the manipulations were carried out in a single test-tube to eliminate the losses inherent in transferring the small amounts of material which were available for analysis. Quickfit test-tubes $8 \mathrm{~cm}$. in overall length 
with B 14 sockets were found to be convenient. The material ( $20 \mathrm{mg}$. for the whole organism and fractions (i), (ii) and (iv), and $80 \mathrm{mg}$. for fraction (iii)) was weighed into a stoppered B 14 tube. One ml. of $95 \%$ methanol was added, and the material was heated under reflux for $1 \mathrm{hr}$. to break down the lipidprotein complexes (Reichert, 1944). The methanol was evaporated, and after drying the material in vacuo over $\mathrm{P}_{2} \mathrm{O}_{5}$ for $15 \mathrm{~min}$., it was extracted for $5 \mathrm{hr}$. with sodium-dried ether in an apparatus designed to obviate the transfer of the material from the Quickfit tube (Mitchell, 1951). The process of heating with methanol and extraction with ether was repeated until no more lipid could be extracted, not more than three extractions usually being required. After evaporating the combined ether extracts to dryness, the lipid was taken up in a small volume of ether, transferred to a weighing tube and dried in vacuo over $\mathbf{P}_{2} \mathbf{O}_{5}$. It was weighed and then redissolved in ether and samples were taken for estimation of phosphate (lipid P). The cell residue in the Quickfit tube was dried and reweighed. It was then dispersed in $2.5 \mathrm{ml}$. distilled water and $0.5 \mathrm{ml} .30 \%(\mathrm{w} / \mathrm{v})$ trichloroacetic acid was added. The residue was centrifuged down and washed twice with $2 \mathrm{ml}$. distilled water, and the washings were combined with the trichloroacetic acid extract and made up to $10 \mathrm{ml}$. for estimation of the 'acid-soluble $\mathbf{P}$ ' on suitable samples. The cell residue was dried and then dissolved by incubation with $2 \mathrm{ml} . \mathrm{N}-\mathrm{NaOH}$ at $35^{\circ}$ for $15 \mathrm{hr}$. The desoxyribonucleic acid (DNA) was precipitated by adding $0.2 \mathrm{ml} .10 \mathrm{~N}-\mathrm{HCl}$ and $\mathbf{0 . 4 4} \mathrm{ml} .30 \%(\mathrm{w} / \mathrm{v})$ trichloroacetic acid. After centrifuging down the DNA, the ribonucleic acid (RNA) and 'excess phosphate' (XSP) were determined by estimations of organic phosphate and of the extinction at $260 \mathrm{~m} \mu$. of the centrifugate, as previously described (Mitchell \& Moyle, 1951b). The DNA was measured by the organic phosphate content of the residue after washing once with distilled water and dissolving in $1 \mathrm{ml}$. $\mathrm{N}-\mathrm{NaOH}$. The distribution of the phosphate in the cell fractions is compared with that of the intact cell in Table 3. The envelope and small particle fractions contain a total of $68 \%$ of the XSP of the whole cell and only traces of nucleic acids, while the soluble fraction contains most of the nucleic acids. A further $18 \%$ of the XSP is present in the residue fraction, leaving only $14 \%$ in the soluble fraction. The lipid phosphate of the envelope fraction is very small, but the small particle fraction contains $30 \%$ of the total lipid phosphate. In general, the values obtained for the sum of the fractions agree well with those for the whole cell-indicating that changes due to autolysis during the mechanical disintegration of the cells cannot be serious. The discrepancy is greatest in the case of the RNA values, where the sum of the values for the fractions falls $17 \%$ below that for the intact organism. This drop, which has been repeatedly observed, is due to a decrease in the apparent purinepyrimidine extinction coefficient, for it is not accompanied by a loss of organic phosphate. For this reason, the XSP values show a corresponding rise in the soluble fraction. Allowing for this error, the XSP value of the soluble fraction would be $35 \mu \mathrm{mol} . / \mathrm{g}$. cell dry weight.

In the evaluation of the RNA content of whole cells from the extinction of the RNA fraction at $260 \mathrm{~m} \mu$. it has been our practice not to correct for the 
relatively insignificant light absorption by substances other than purines and pyrimidines. For the very small RNA values found in the envelope and small particle fractions, however, the absorption of light by substances other than

Table 3. Distribution of phosphate in cell fractions and whole cells of Micrococcus pyogenes

\begin{tabular}{|c|c|c|c|c|c|c|}
\hline \multirow{2}{*}{$\begin{array}{l}\text { Phosphate } \\
\text { fraction }\end{array}$} & \multicolumn{4}{|c|}{ Fractions } & \multirow{2}{*}{$\begin{array}{l}\text { Sum of } \\
\text { (i) to (iv) }\end{array}$} & \multirow[b]{2}{*}{$\begin{array}{l}\text { Whole } \\
\text { cell }\end{array}$} \\
\hline & (i) & (ii) & (iii) & (iv) & & \\
\hline $\begin{array}{l}\text { Acid soluble } \\
\text { inorganic }\end{array}$ & $\mathbf{0}$ & $\mathbf{2 \cdot 5}$ & 157 & $1 \cdot 6$ & 161 & 166 \\
\hline $\begin{array}{c}\text { Acid soluble } \\
\text { organic }\end{array}$ & $\mathbf{0}$ & $1 \cdot 9$ & 117 & $1 \cdot 2$ & 120 & 110 \\
\hline Lipid & $0 \cdot 12$ & $11 \cdot 3$ & $20 \cdot 5$ & $3 \cdot 7$ & $35 \cdot 6$ & 38 \\
\hline RNA & 3.1 & $5 \cdot 2$ & $137(170)$ & $19 \cdot 0$ & $164(197)$ & 197 \\
\hline XSP & 126 & 43 & $61(35)$ & 46 & 276 (250) & 250 \\
\hline DNA & 3.0 & $1 \cdot 2$ & 59 & $6 \cdot 8$ & 70 & 73 \\
\hline
\end{tabular}

The values given in the body of the Table are the $\mu$ mol. of phosphate present in the appropriate fraction/g. of dry organism. Values in brackets are corrected for change of apparent extinction coefficient of the RNA fraction at $260 \mathrm{~m} \mu$. after disintegration of the cells.

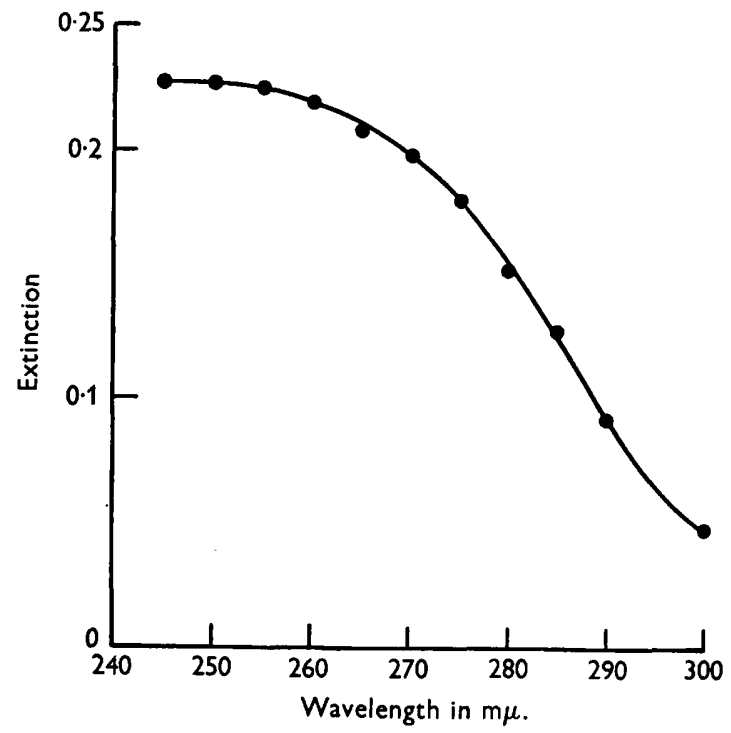

Fig. 1. Absorption spectrum of the so-called RNA of the envelope fraction in acid solution at a concentration corresponding to $1 \mathrm{mg}$. cell dry weight/ml.

purines and pyrimidines should not be neglected. This was demonstrated by the absorption spectrum of the so-called RNA of the envelope fraction, shown in Fig. 1, which does not correspond to the spectrum of a ribonucleic acid. Hence the already low RNA values for the envelope fraction and probably also for the small particle fraction are erroneously high. 


\section{Estimation of polyolphosphates of fractions (i) and (ii)}

The solution containing the XSP of fractions (i) and (ii) was adjusted to pH 9 after centrifuging down the DNA and taking the small samples required for the estimations described above. Ethanol ( 2 vol.) was added and the fine precipitate was allowed to adhere to the glass during 2 days. The clear supernatant was decanted and the barium salt of the polyolphosphates was precipitated on adding 10 equivalents of $\mathrm{M}-\mathrm{BaCl}_{2}$. The barium salt was centrifuged down, washed once with a little $60 \%$ ethanol and dried. The polyolphosphoric acids were liberated from the barium salt by grinding with $0 \cdot 1 \mathrm{ml} \cdot 0 \cdot 1 \mathrm{~N}-\mathrm{H}_{2} \mathrm{SO}_{4} /$ mg., and after removing the barium sulphate by centrifuging, $10 \mu \mathrm{l}$. samples of the solution were taken for estimation of total organic phosphate and for chromatographic determination of the ratio of glycerophosphate (GP) to the unidentified polyolphosphates (IP) as previously described (Mitchell \& Moyle,

Table 4. The recovery of GP and IP from the XSP of fractions (i) and (ii)

\begin{tabular}{|c|c|c|c|}
\hline Component & $\begin{array}{c}\mu \mathrm{mol} . / \mathrm{g} . \\
\text { dry wt. cells }\end{array}$ & $\begin{array}{l}\text { Percentage } \\
\text { recovery } \\
\text { of XSP of } \\
\text { fraction }\end{array}$ & $\begin{array}{c}\text { Percentage } \\
\text { of whole } \\
\text { cell XSP }\end{array}$ \\
\hline \multicolumn{4}{|c|}{ Envelope fraction (i) } \\
\hline XSP & 126 & - & 51 \\
\hline GP & 92 & 73 & 36 \\
\hline IP & 18 & 15 & 8 \\
\hline $\mathbf{G P}+\mathbf{I P}$ & 110 & 88 & 44 \\
\hline \multicolumn{4}{|c|}{ Small particle fraction (ii) } \\
\hline XSP & 43 & - & 17 \\
\hline GP & 29 & 68 & 12 \\
\hline IP & 10 & 23 & 4 \\
\hline GP + IP & 39 & 91 & 16 \\
\hline
\end{tabular}

The XSP values are computed by the difference total organic P-RNA. The GP and IP values are determined by estimations of phosphate after isolation of the mixed barium salt and chromatographic separation of the phosphate esters.

$1951 b$ ). The chromatograms (run in $60 \mathrm{ml} . n$-propanol $/ 30 \mathrm{ml} .20 \mathrm{~N}$ ammonia $+10 \mathrm{ml}$. water) showed spots corresponding only to GP $\left(R_{F}=0 \cdot 30\right)$ and IP $\left(R_{F}=0 \cdot 12\right)$. The yields and proportions of the polyolphosphates are described in Table 4. The recovery of both GP and IP is higher than was obtained from the whole cell, as would be expected. The interpretation of the proportions of the polyolphosphates obtained in the alkali hydrolysate will be dealt with in a later communication.

\section{Purity of the cell fractions}

The fractions of the disintegrated cells have been separated by taking advantage of differences in particle size and density, but the aim has been to obtain a separation of anatomical units of the cell, and it is in this sense that the purity of the fractions must be judged. The electron micrographs showed that the differences in particle size and density were accompanied by distinct morphological characteristics; but only in the case of fraction (i) (the envelope fraction) could the material be recognized as part of an anatomical unit of the 
cell. The distribution of organic phosphate compounds in the fractions shows that while there are profound differences between the compositions of the envelope and soluble fractions, the small particle fraction differs significantly from the envelope fraction only in containing more phospholipid. We therefore consider it possible that the small particle fraction may have been artificially produced during disintegration of the cells, and that in the intact cell the material of this fraction constitutes part of the cell envelope. The small amounts of nucleic acids found in the envelope and small particle fractions give an indication of the possible degree of contamination of these fractions with the material of the soluble fraction, while the corrected XSP content of the soluble fraction indicates the possible degree of loss of the particulate fractions by solubilization (autolysis?) during the process of cell disintegration.

In order to shed light on the possible modes of attachment of the glycerophosphate, we now proceeded to examine the lipid, carbohydrate and nitrogencontaining components of the particulate fractions.

\section{Composition of the cell fractions}

Estimation of nitrogen. Kjeldahl nitrogen was determined by a colorimetric iodomercurate method similar to that of Umbreit, Burris \& Stauffer (1949), giving values with a standard deviation of $\pm 3 \%$ for samples of $1-5 \mu \mathrm{g}$. Estimations of Van Slyke $\alpha$-amino nitrogen were kindly made by Dr Haselbach on hydrolysates prepared by heating the material with $5 \mathrm{~N}-\mathrm{HCl}$ at $100^{\circ}$ for 24. hr. in sealed tubes.

Estimation of carbohydrate. Total carbohydrate was estimated by the quantitative adaptation of Dreywood's anthrone reaction method developed by Seifter, Dayton, Novic \& Muntwyler (1950). For identification of the sugars, the material was hydrolysed by heating at $100^{\circ}$ with methanolic- $\mathrm{HCl}$ in sealed tubes for $18 \mathrm{hr}$., evaporation to dryness in vacuo over $\mathrm{NaOH}$ pellets and heating at $100^{\circ}$ for $18 \mathrm{hr}$. in aqueous $\mathrm{N}-\mathrm{HCl}$ to hydrolyse the methyl glycosides. The hydrolysates were run on chromatograms in pyridine (1 vol.), water (2 vol.), ethyl acetate ( 2 vol.) at $25^{\circ}$ on Whatman no. 1 paper, the upper layer being used as the moving phase. The chromatograms were developed with $1 \%$ aniline phthalate in butanol, the presence of glucosamine being confirmed in duplicate chromatograms by spraying with $0.2 \%$ ninhydrin in water-saturated butanol. The amount of glucosamine present was estimated very approximately by comparing the intensity of the aniline phthalate and ninhydrin spots with standards of known concentration.

Estimation of lipid. The total loosely bound lipid was estimated gravimetrically after extraction with solvents as described above. Lipid not extracted by this procedure was obtained by carrying out a similar extraction after hydrolysing the material with $5 \mathrm{~N}-\mathrm{HCl}$ at $100^{\circ}$ for $24 \mathrm{hr}$. The lipid thus obtained was freed from traces of glycerol by redissolving in a small volume of ether before being dried over $\mathrm{P}_{2} \mathrm{O}_{5}$ and weighed.

Results. The estimations of protein, lipid and carbohydrate components of the fractions are shown in Table 5. The protein weight was calculated from the 
non-lipid Kjeldahl nitrogen weight using a multiplying factor of $6 \cdot 2$, and the weight of polyolphosphoric acid was taken as five times the weight of XSP phosphorus.

It is apparent that the main components of the envelope and small particle fractions are the polyolphosphoric acids, protein and lipid. Part of the lipid is readily separated from the other two components by extraction with organic solvents, but it has not proved to be possible to separate the polyolphosphoric acids from the protein except by methods which hydrolyse the latter. The following solutions were found to exert no solvent action either on the protein or on the polyolphosphoric acids of the envelope fraction in $1 \mathrm{hr}$.: water at $25^{\circ}$ or at $100^{\circ}$; hot or cold methanol, ethanol, $n$-butanol or ether; 5 or $90 \%$ $\left(\mathrm{w} / \mathrm{v}\right.$ ) aqueous phenol at $25^{\circ} ; 50 \%(\mathrm{w} / \mathrm{v})$ aqueous guanidine hydrochloride, pure $N$-dimethylformamide or $70 \%(\mathrm{w} / \mathrm{v})$ aqueous $N$-dimethylformamide at $25^{\circ} ; 5 \%(\mathrm{w} / \mathrm{v})$ trichloroacetic acid, $\mathrm{N}$ acetic acid or $10 \mathrm{~N}$ aqueous ammonia at $25^{\circ} ; 0.1 \mathrm{~N}-\mathrm{NaOH}$ or $0.1 \mathrm{~N}-\mathrm{HCl}$ at $0^{\circ}$; water $/ 0.1 \%(\mathrm{w} / \mathrm{v})$ oxine in $n$-amyl alcohol

Table 5. Composition of envelope and small particle fractions of

Micrococcus pyogenes

\begin{tabular}{|c|c|c|}
\hline \multirow[b]{2}{*}{$\begin{array}{l}\text { Substance } \\
\text { estimated }\end{array}$} & \multicolumn{2}{|c|}{$\begin{array}{l}\text { Weight of substance in } \\
\mathrm{mg} \cdot / 100 \mathrm{mg} . \text { of fraction }\end{array}$} \\
\hline & $\begin{array}{l}\text { Envelope } \\
\text { fraction }\end{array}$ & $\begin{array}{l}\text { Small particle } \\
\text { fraction }\end{array}$ \\
\hline $\begin{array}{l}\text { Total Kjeldahl N } \\
\text { Lipid Kjeldahl N } \\
\text { Non-lipid Kjeldahl N } \\
\text { Van Slyke } \alpha \text {-amino N }\end{array}$ & $\begin{array}{l}10 \cdot 6 \\
0 \cdot 70 \\
9 \cdot 9 \\
10 \cdot 1\end{array}$ & $\begin{array}{l}9 \cdot 5 \\
3 \cdot 0 \\
6 \cdot 5 \\
6 \cdot 9\end{array}$ \\
\hline Protein & 62 & 41 \\
\hline Polyolphosphoric acid & 12 & 8 \\
\hline Lipid (direct extraction) & $\mathbf{3} \cdot \mathbf{2}$ & $22 \cdot 5$ \\
\hline Lipid (from hydrolysate) & $4 \cdot 4$ & - \\
\hline Glucose & 0.5 & $1 \cdot 7$ \\
\hline Glucosamine & c. 1 & c. 3 \\
\hline RNA & $0 \cdot 6$ & $2 \cdot 4$ \\
\hline DNA & $0 \cdot 6$ & $0 \cdot 5$ \\
\hline Total recovery & 84 & 79 \\
\hline
\end{tabular}

at $25^{\circ}$. On the other hand, when the envelope fraction was slowly hydrolysed by suspension in $\mathrm{N}-\mathrm{HCl}$ at $35^{\circ}$, organic phosphate and protein were found to go into solution at a constant rate, about $40 \%$ of the protein and $80 \%$ of the organic phosphate being solubilized in $5 \mathrm{hr}$. Solubilization of protein and organic phosphate took place at about the same rate on hydrolysis with $\mathrm{N}-\mathrm{NaOH}$ at $0^{\circ}$ or $10 \mathrm{~N}$ ammonia at $100^{\circ}$ as with $\mathrm{N}-\mathrm{HCl}$ at $35^{\circ}$.

A more specific hydrolysis of components of the glycerophospho-protein complex might be obtained by enzymic degradation, but so far the material has proved to be resistant. Treatment of the envelope fraction for $3 \mathrm{hr}$. at $35^{\circ}$ with crystalline pepsin at $\mathrm{pH} 1$ or 2 , crude trypsin at $\mathrm{pH} 7 \cdot 5$, crystalline egg-white lysozyme in $0.5 \% \mathrm{NaCl}$ at $\mathrm{pH} 7$, intestinal alkaline phosphomonoesterase at $\mathrm{pH} 9.7$ in the presence of $0.001 \mathrm{M}-\mathrm{MgCl}_{2}$, or crystalline pancreatic ribonuclease at $\mathrm{pH} 7 \cdot 5$ caused no solubilization of phosphate or protein. A 
preliminary treatment of the envelope fraction in water at $100^{\circ}$ for $30 \mathrm{~min}$. made no difference to the action of the above enzymes.

The possibility was considered that the polyolphosphoric acids might be present as a polymer adsorbed on to the protein of the envelope fraction. On the other hand, the evidence available did not exclude the possibility that whether present as a polymer or not the polyolphosphoric acids might be linked covalently to the protein, either directly or through one or more unknown compounds accounting for the $16 \%$ of the weight of the envelope fraction still to be identified.

It was clear at this stage that a knowledge of the approximate amino-acid composition of the envelope fraction would materially assist in our considerations of the possible mode of attachment of the polyolphosphoric acids.

\section{Amino-acid composition of the protein of the envelope fraction}

The lipid was extracted from the envelope fraction with organic solvents as before, and $10 \mathrm{mg}$. samples were heated for $24 \mathrm{hr}$. with $5 \mathrm{~N}-\mathrm{HCl}$ at $100^{\circ}$ in sealed tubes. The hydrolysate was dried in vacuo over $\mathrm{NaOH}$ pellets and $\mathrm{P}_{2} \mathrm{O}_{5}$, and redissolved in water to give a concentration of $1 \%$. The amino-acid composition was determined by running 5, 10 and $20 \mu$ l. samples of the

Table 6. Approximate amino-acid composition of the acid hydrolysate of the envelope fraction of Micrococcus pyogenes

$\begin{array}{lcc}\text { Amino-acid } & \begin{array}{c}\text { No. of } \\ \text { residues }\end{array} & \begin{array}{c}\mu \mathrm{mol} . / \mathrm{g} . \\ \text { cell dry wt. }\end{array} \\ \text { Glycine } & \mathbf{2 0} & \mathbf{3 5 0} \\ \text { Alanine } & 17 & \mathbf{2 9 0} \\ \text { Glutamic acid } & 11 & 190 \\ \text { Lysine } & 7 & 120 \\ \text { Serine } & 4 & \mathbf{7 0} \\ \text { Threonine } & 4 & \mathbf{7 0} \\ \text { Leucine +isoleucine } & \mathbf{3} & \mathbf{5 0} \\ \text { Aspartic acid } & 2 & \mathbf{3 5} \\ \text { Valine } & 1 & 15 \\ \text { Histidine } & <\mathbf{1} & - \\ \text { Arginine } & <\mathbf{0 . 5} & -\end{array}$

Other amino-acids present in smaller amount than arginine, not determined.

hydrolysate on one-dimensional paper chromatograms and measuring the ninhydrin-reacting material eluted from the appropriate areas of the paper by the method of Boissonas (1950). The moving phase used for the chromatograms was phenol saturated with water, and in order to obtain adequate separation of the amino-acids on Whatman no. 1 paper at $25^{\circ}$, the equilibrating phase was varied from equal weights of phenol and water +a trace of $\mathrm{KCN}$ to equal parts of phenol and water $+0.1,0.5$ and $3.0 \%(v / v)$ of $20 \mathrm{~N}$ ammonia. A high degree of accuracy has been claimed for Boissonas's method, but owing to unaccountable variations which occasionally occurred in our results we considered that significance should not be given to determinations of molecular amounts of amino-acid less than one-twentieth of the amount of glycine present in our hydrolysates. The relative numbers of amino-acid residues are therefore given in Table 6 with glycine written as 20. It is evident that the amino-acid 
composition of the whole protein of the envelope resembles that of silk fibroin more closely than that of any other protein for which analyses are available (Tristram, 1949). It differs from silk fibroin mainly in containing relatively much less tyrosine, but more threonine. There is, of course, no evidence that the protein of the envelope fraction can legitimately be regarded as homogeneous, but at all events, a composition resembling that of silk fibroin is the least unexpected of the highly resistant and insoluble material of the protein envelope.

The second column of Table 6 shows the amounts of the amino-acids of the envelope fraction expressed as $\mu \mathrm{mol} . / \mathrm{g}$. cell dry weight for comparison with the figures of Table 3. Since the total amount of serine and threonine in the envelope fraction is estimated as $140 \mu \mathrm{mol}$. and that of polyolphosphoric acid phosphorus as $126 \mu \mathrm{mol} . / \mathrm{g}$., it would be possible for the polyolphosphoric acids to be linked to the protein through the hydroxylamino-acids. This possibility is now under investigation.

\section{DISCUSSION}

Because of the preponderance of protein in the envelope of $M$. pyogenes isolated after mechanical disintegration of the cells, we propose for the present to refer to it as the protein envelope to distinguish it from other layers of less mechanically resistant material which may lie internally or externally to it in the intact cell. A more detailed knowledge of its chemical structure will probably suggest a more specific name for the protein envelope by which it may be distinguished from other envelopes also of a protein nature which may be discovered. It is evident that the polyolphosphoric acids are firmly bound to the protein envelope, either as a polymerized complex (possibly forming a continuous layer) or dispersed in the protein matrix. The phosphate radicals of the polyolphosphoric acids may be covalently linked to the protein, but until this linkage has been proved it is advisable to refer to the compound as a phospho-protein complex rather than as a phospho-protein.

When $\boldsymbol{M}$. pyogenes is treated with $5 \%$ trichloroacetic acid or with phenol or other detergents or organic solvents the osmotic barrier (Mitchell, 1949) is broken and diffusible substances of molecular size not usually exceeding that of the nucleotides escape or can be washed from the cells, although under these conditions the protein envelope is not removed. It seems likely, therefore, that the protein envelope should not be considered as an impervious sheet of peptide chains, but as a pervious network of chains or fibres with an effective maximum pore diameter of $c .1 \mathrm{~m} \mu$. In the intact cell, this protein envelope presumably acts as the support for the osmotic barrier, part of which may be built into the protein matrix. Cytological evidence indicates the presence of a lipid layer, readily stained by hydrophobic, lipid-soluble dyes such as Sudan black (Burdon, 1946), usually thought to represent the osmotic barrier. This lipid layer lies inside the 'cell wall' which is characterized by a very low affinity for dyes (Knaysi, 1951). In view of the similarity of composition of the non-lipid moiety of the small particle fraction obtained from disintegrated $M$. pyogenes, we suggest that the material of the small particle fraction may be 
associated with the protein envelope in the intact cell and that the lipid of the small particle fraction may form the layer which is stained by Sudan black. Thus, the protein envelope would correspond to the 'cell wall' and the small particle fraction would contribute the underlying lipid membrane.

Taking into account the weight and composition of the residue fraction, the protein envelope can be estimated to account for $c .20 \%$ of the cell dry weight and the small particle fraction for $c$. $10 \%$. The cells are about $0.7 \mu$. in diameter at the time of harvesting (Mitchell \& Moyle, 1951 $a$ ) and consequently, assuming the superficial layers to be hydrated to the same extent as the rest of the cell, the envelope fraction would form a surface layer c. $25 \mathrm{~m} \mu$. thick, while in combination with the small particle fraction it would form a layer c. $40 \mathrm{~m} \mu$. thick-well below the limit of resolution, but not, of course, below the limit of visibility of the light microscope.

The concept of the protein envelope of $M$. pyogenes as a structural component might be taken as an indication of metabolic inertness, particularly in view of the resistance of the material to enzymic degradation; but it does not follow that because a structure performs a mechanical function that it may not also be involved in a metabolic one, particularly in a system which might be concerned with the transport of metabolites such as amino-acids across an osmotic barrier. It is with this consideration in mind that we are now examining the nature of the glycerophospho-protein complex which, from the envelope fraction alone, accounts for more than $20 \%$ of the total organic phosphate of the cell.

We would like to express our indebtedness to Prof. F. G. Young for his wise council and support. Our thanks are also due to the Medical Research Council for grants which have largely financed this work.

\section{REFERENCES}

Borssonas, R. A. (1950). Dosage colorimetrique des acides aminés séparé par chromatographie sur papier. Helv. chim. Acta, 33, 1975.

Burdon, K. L. (1946). Fatty material in bacteria and fungi revealed by staining dried, fixed slide preparations. J. Bact. 52, 665 .

Dawson, I. M. (1949). The Nature of the Bacterial Surface, p. 119 and PI. 5. Ed. Miles, A. A. and Pirie, N. W. Oxford: Blackwell.

KNAYsI, G. (1951). Elements of Bacterial Cytology, 2nd ed. Ithaca, N.Y., U.S.A.: Comstock Publishing Co.

MickLe, H. (1948). Tissue disintegration. J. R. micr. Soc. 68, 10.

Mitcheld, P. (1949). The osmotic barrier in bacteria. The Nature of the Bacterial Surface, p. 55. Ed. Miles, A. A. and Pirie, N. W. Oxford: Blackwell.

Mrtcheld, P. (1951). A micro lipid extractor. Nature, Lond., (in press).

Mrtchell, P. \& Moyle, J. (1950). Occurrence of a phosphoric ester in certain bacteria : its relation to Gram staining and penicillin sensitivity. Nature, Lond., 166, 218.

Mrtcheld, P. \& Moyle, J. (1951 $a$ ). Relationships between cell growth, surface properties and production of free nucleotide and nucleic acids in normal and penicillin-treated Micrococcus pyogenes. J. gen. Microbiol. 5, 421.

Mitchell, P. \& Moyle, J. (1951b). Isolation of hydrolytic products of a glycerophospho-compound from Micrococcus pyogenes. J.gen. Microbiol. 5, 966. 
Reichert, R. (1944). Quantitative Bestimmung des Gesamtlipoidgehaltes von Naturstoffen. Helv. chim. Acta, 27, 961.

Seifter, S., Dayton, S., Novic, B. \& Muntwyler, E. (1950). Estimation of glycogen with the anthrone reagent. Arch. Biochem. 25, 191.

Sevag, M. G. \& Smolens, J. (1941). Studies on the conjugation of streptococcal nucleoprotein. J. biol. Chem. 140, 833.

Tristram, G. R. (1949). Amino-acid composition of purified proteins. Advances in Protein Chemistry, 5, 83.

Umbreit, H. W., Burris, R. H. \& Stauffer, J. F. (1949). Manometric Techniques and Tissue Metabolism. Minneapolis: Burgess.

(Received 11 June 1951) 